Article

\title{
Biogas from Fresh Spring and Summer Grass: Effect of the Harvesting Period
}

\author{
Alessandro Chiumenti ${ }^{1}$, Davide Boscaro ${ }^{2}$, Francesco da Borso ${ }^{1}$, Luigi Sartori ${ }^{2}$ and \\ Andrea Pezzuolo $2, *$ \\ 1 Department of Agricultural, Food, Animal and Environmental Sciences (DI4A), University of Udine, \\ 33100 Udine, Italy; alessandro.chiumenti@uniud.it (A.C.); francesco.daborso@uniud.it (F.d.B.) \\ 2 Department of Agroforesty and Landscape, University of Padua, 35020 Legnaro, Italy; \\ davide.boscaro@unipd.it (D.B.); luigi.sartori@unipd.it (L.S.) \\ * Correspondence: andrea.pezzuolo@unipd.it
}

Received: 3 May 2018; Accepted: 4 June 2018; Published: 6 June 2018

Abstract: Yard trimmings, landscape management and agricultural practices determine the collection of biomass currently destined mainly to the production of a valuable soil amendant by composting. While composting requires energy, especially for the turning/aeration phases and for air treatment (i.e., biofilters in the case of enclosed systems), anaerobic digestion represents an energy positive process that results in production of biogas and digestate, which can be used as fuel and fertilizer, respectively. The focus of the present research was the evaluation of biogas and methane potential of grass collected in two different periods of the year (spring and summer) from riverbanks located in Northern Italy. The conversion to biogas of feedstocks is greatly influenced by the composition of the organic matter, content of cellulose, and lignin in particular. The production of biomass per hectare and the consequent biogas production were also evaluated. The experimental tests were performed on both samples of fresh grass in laboratory scale batch reactors, characterized by $4.0 \mathrm{~L}$ of volume and operated in mesophilic conditions $\left(38^{\circ} \mathrm{C}\right)$, for 40 days per cycle. The anaerobic digestion process was performed on a mixture of inoculum and grass, characterized by inoculum:substrate VS (volatile solids) ratio equal to 2 . The inoculum was represented by digestate from a full-scale anaerobic digestion plant fed with dairy cow manure. The results in terms of biogas production, biogas quality $\left(\mathrm{CH}_{4}, \mathrm{CO}_{2}, \mathrm{H}_{2} \mathrm{~S}\right)$, and emissions from digestates $\left(\mathrm{NH}_{3}, \mathrm{CO}_{2}\right.$ and $\left.\mathrm{CH}_{4}\right)$ are presented in the paper. Total solids (TS), volatile solids (VS), $\mathrm{pH}$, volatile fatty acids (VFA), alkalinity, acidity vs. alkalinity ratio, fibers (cellulose, lignin), and total Kjieldahl nitrogen (TKN) were determined both on input and output of the process. The biogas yield obtained from grass resulted higher than expected, quite similar to the yield obtained from energy crops, with Biomethane Potential (BMP) of $340.2 \mathrm{NL} \cdot \mathrm{kg}^{-1} \mathrm{VS}$ and of $307.7 \mathrm{NL} \cdot \mathrm{kg}^{-1} \mathrm{VS}$, respectively, for spring and summer grass. Biogas quality was slightly lower for summer grass, perhaps in relation to the higher content of fibers (lignin). Alternatively, the yield of grass per surface was significantly different between spring and summer with the highest production in the summer. In fact, the results revealed a methane yield of $263 \mathrm{Nm}^{3} \cdot \mathrm{ha}^{-1}$ and of $1181 \mathrm{Nm}^{3} \cdot \mathrm{ha}^{-1}$, respectively for spring and summer grass.

Keywords: energy source; anaerobic digestion; biomethane; biogas potential; BMP; grass

\section{Introduction}

Sustainable development is a current notion strictly related to the concept of a circular economy. In this optic, the production of renewable energy by the valorization of wastes or by-products is considered as one of the most dominant future renewable energy sources [1-5]. 
Anaerobic digestion (AD) represents one of the most valuable technologies for the management of fermentable organic wastes [6]. This energy positive process not only renders high value products such as fuel, biogas, and a fertilizer, namely digestate $[7,8]$, but also determines a significant reduction of the emissions of greenhouse gases [9], methane $\left(\mathrm{CH}_{4}\right)$, and carbon dioxide $\left(\mathrm{CO}_{2}\right)$ in particular, and of odours deriving form uncontrolled fermentations [10].

Landscape management or agricultural processes produce a significant amount of biomass that could represent a potential feedstock for anaerobic digestion but is not completely exploited in the anaerobic digestion sector [11,12]. In fact, the main destination of these products is currently represented by composting, a tested process that results in the production of a valuable product, compost, but that also demands energy for the turning/aeration phases and air treatment (i.e., biofilters in case of enclosed systems) [13]. Biomass with high content of lignin (e.g., branches, wood) is best suitable for gasification or incineration and for the composting process as bulking agent [14].

Alternatively, landscape grass, consisting of a herbaceous plant composite, could represent one of the most promising feedstocks to improve the sustainability of the biogas sector $[15,16]$. Accordingly, this biomass does not compete with food production, and it is widely available within the Italian territory [17], including uncultivated areas throughout the territory of Veneto [18]. Although there are still no studies aimed to define its quantity and composition, the territory is evidently characterized by a large quantity of biomass [19].

Principally, its botanical composition is categorized by Poaceae spp., Fabaceae spp. or Asteracee spp. [20,21]; however various types of species can be founded depending on the area of origin. Grass, by reason of its characteristics, is an interesting feedstock that can be used in the biogas supply-chain [22]. Various authors report benefits in terms of net energy yields from grass (Poaceae) compared to maize (Zea mays L.) in terms of MWh from renewable sources per MWh of fossil energy invested, considering that grass is a residual product while maize is a dedicated culture [23]. A laboratory biomethane potential assay is often conducted to verify the degradability of potential feedstocks $[24,25]$.

The biogas potential of switchgrass (Panicum capillare L.) was evaluated in codigestion with different animal manure mixtures by Ahn and colleagues [26] in a dry AD process, while the specific potential of grass was evaluated in batch leach bed by Lehtomäki et al. [27] and in a two-phase system [28].

The focus of the present work was the evaluation of the specific biogas and methane potential, in a wet AD process, of fresh grass collected from riverbanks located in Veneto, Northern Italy in two different periods, spring and summer. The following analysis also presents the results in terms of potential gaseous emissions from digestates $\left(\mathrm{NH}_{3}, \mathrm{CO}_{2}\right.$ and $\left.\mathrm{CH}_{4}\right)$.

\section{Material and Methods}

\subsection{Experimental Site and Field Operations}

Tests were performed on grass collected from riverbanks of the Adige river in the area of Boara Pisani-Northern Italy (coordinates: $45^{\circ} 5^{\prime} 53.73^{\prime \prime} \mathrm{N}, 11^{\circ} 43^{\prime} 39.19^{\prime \prime} \mathrm{E}$ ). Soil type is mainly sandy-loam and the climate of the area is characterized by average annual temperature of $13.7^{\circ} \mathrm{C}$, average annual rainfall of $835 \mathrm{~mm} \cdot$ year $^{-1}$, occurring mainly in the spring.

Grass was collected in two different periods, spring and early summer, from the same plot of land in two different areas. The collection was performed manually, by means of scissors, simulating the harvesting operation of traditional forage equipment (e.g., cutting and baling or harvesting by self-loading wagon), achieving a final size of $40 \mathrm{~mm}$ (Figure 1).

The potential grass yield ( $t$ of fresh matter per hectare) was determined by the harvesting and determination of mass of grass samples in ten $0.16 \mathrm{~m}^{2}$ random areas within each site. The average value obtained was considered as grass yield. Grass samples were immediately transported to the research facility. 

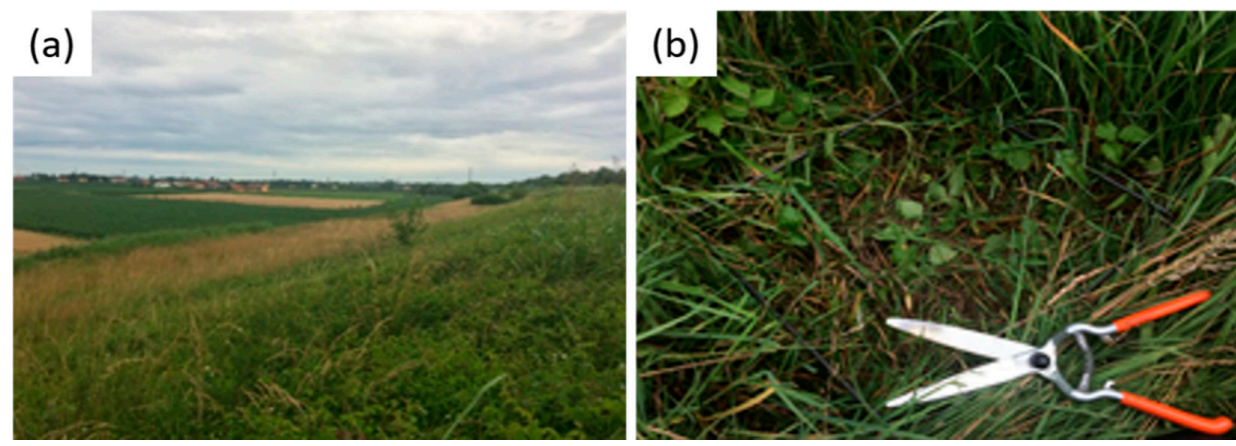

Figure 1. View of the harvesting area (a) and detail of the grass harvesting plot (b).

\subsection{Lab Scale Anaerobic Digestion System and Experimental Setup}

The lab scale AD system was composed of six digesters, each with a volume of $4 \mathrm{~L}$ and equipped with propeller-type mixers (Figure 2). Temperature control was achieved by a thermostatic bath heated by an electric resistance controlled by a digital thermostat with a water recirculation pump to maintain homogeneous conditions in the tank.

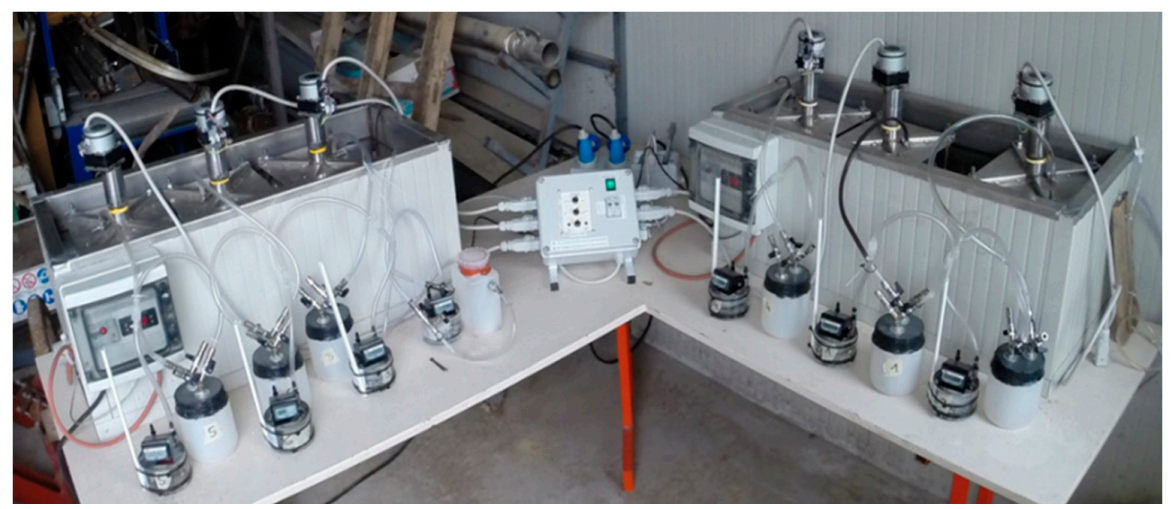

Figure 2. Detail of the experimental anaerobic digestion system.

The biogas line was composed by condensation traps and biogas meters (MilliGascounter ${ }^{\circledR}$, Ritter, Bochum, Germany) that continuously registered the volume of produced biogas, normalizing it at the normal conditions of temperature and pressure $(273.15 \mathrm{~K} ; 101.33 \mathrm{kPa})$. Biogas quality $\left(\mathrm{CH}_{4}\right.$, and $\left.\mathrm{CO}_{2}\right)$ was determined by Siemens Ultramat IR analyzer (Siemens Automation Group, Karlsruhe, Germany) and ProTec gas pump with Kitagawa (Kitagawa, Japan) detection tubes $\left(\mathrm{H}_{2} \mathrm{~S}\right)$.

Digestate from a full scale biogas plant (65 kWe, 30 days Hydraulic Retention Time (HRT), mesophilic $-39{ }^{\circ} \mathrm{C}$, single stage), was chosen as inoculum, considering its relatively stable characteristics deriving from the use of a single feedstock (cow manure) as input (Table 1).

Table 1. Characteristics of the inoculum, of spring and summer grass and of digestate from the tests (n.d. indicates not determined).

\begin{tabular}{|c|c|c|c|c|c|c|c|c|c|c|}
\hline Feedstock & $\begin{array}{l}\text { TS } \\
(\%)\end{array}$ & $\begin{array}{c}\text { VS } \\
\text { (\%TS) }\end{array}$ & $\mathrm{pH}$ & $\begin{array}{l}\text { Redox } \\
\text { (mV) }\end{array}$ & $\begin{array}{c}\text { Acidity/ } \\
\text { Alkalinity }\end{array}$ & $\begin{array}{c}\text { TKN } \\
\left(\mathrm{g} \cdot \mathrm{kg}^{-1}\right)\end{array}$ & $\begin{array}{c}\mathrm{NH}_{4}^{+} \\
\left(\mathrm{g} \cdot \mathrm{kg}^{-1}\right)\end{array}$ & $\begin{array}{l}\text { Lignin } \\
\text { (\%TS) }\end{array}$ & $\begin{array}{c}\text { Cellulose } \\
\text { (\%TS) }\end{array}$ & $\begin{array}{l}\text { Hemicellulose } \\
\text { (\%TS) }\end{array}$ \\
\hline $\begin{array}{l}\text { Spring } \\
\text { Grass }\end{array}$ & $32.43 \pm 2.27$ & $79.21 \pm 0.03$ & n.d & n.d. & n.d. & $7.65 \pm 1.29$ & n.d. & $3.93 \pm 0.43$ & $21.24 \pm 1.35$ & $23.07 \pm 3.32$ \\
\hline $\begin{array}{l}\text { Inoculum } \\
\text { Input Mix * }\end{array}$ & $\begin{array}{c}7.85 \pm 0.09 \\
8.90\end{array}$ & $\begin{array}{c}80.80 \pm 0.05 \\
\quad 68.41\end{array}$ & $\begin{array}{c}8.2 \pm 0.1 \\
\text { n.d }\end{array}$ & $\begin{array}{c}-400 \pm 10 \\
\text { n.d. }\end{array}$ & $\begin{array}{l}0.24 \pm 0.02 \\
\text { n.d. }\end{array}$ & $\begin{array}{c}4.19 \pm 0.41 \\
3.90\end{array}$ & $\begin{array}{l}2.92 \pm 0.35 \\
2.21\end{array}$ & $\begin{array}{c}12.54 \pm 0.69 \\
11.63\end{array}$ & $\begin{array}{c}19.62 \pm 1.21 \\
19.79\end{array}$ & $\begin{array}{c}18.14 \pm 1.20 \\
18.66\end{array}$ \\
\hline Digestate & $6.28 \pm 0.09$ & $71.79 \pm 0.66$ & $7.9 \pm 0.1$ & $-391 \pm 16$ & $0.15 \pm 0.03$ & $3.90 \pm 0.03$ & $2.29 \pm 0.06$ & $11.69 \pm 0.34$ & $12.71 \pm 0.26$ & $13.57 \pm 0.46$ \\
\hline $\begin{array}{l}\text { Summer } \\
\text { Grass }\end{array}$ & $33.30 \pm 4.31$ & $90.26 \pm 1.23$ & n.d & n.d. & n.d. & $10.22 \pm 2.69$ & n.d. & $8.65 \pm 4.25$ & $34.72 \pm 4.96$ & $28.12 \pm 1.22$ \\
\hline $\begin{array}{l}\text { Inoculum } \\
\text { Input Mix* }\end{array}$ & $\begin{array}{c}7.28 \pm 0.10 \\
8.55\end{array}$ & $\begin{array}{c}78.45 \pm 0.06 \\
\quad 67.64\end{array}$ & $\begin{array}{c}7.8 \pm 0.1 \\
\text { n.d }\end{array}$ & $\begin{array}{c}-395 \pm 8 \\
\text { n.d. }\end{array}$ & $\begin{array}{c}0.18 \pm 0.03 \\
\text { n.d. }\end{array}$ & $\begin{array}{c}3.94 \pm 0.28 \\
3.84\end{array}$ & $\begin{array}{c}3.07 \pm 0.27 \\
2.22\end{array}$ & $\begin{array}{c}11.32 \pm 0.90 \\
11.01\end{array}$ & $\begin{array}{c}18.35 \pm 0.99 \\
20.24\end{array}$ & $\begin{array}{c}16.22 \pm 1.22 \\
17.59\end{array}$ \\
\hline Digestate & $6.06 \pm 0.28$ & $76.09 \pm 1.00$ & $7.8 \pm 0.1$ & $-455 \pm 7$ & $0.19 \pm 0.02$ & $3.83 \pm 0.87$ & $2.53 \pm 0.25$ & $12.46 \pm 0.57$ & $12.91 \pm 0.90$ & $11.73 \pm 1.22$ \\
\hline
\end{tabular}


Digesters n. 1, 2, and 3 were filled only with the inoculum $(2.5 \mathrm{~kg})$ in order to determine the residual production from this substrate. Digesters n. 4, 5 and 6 were filled with a mixture of inoculum and fresh grass ( $2.5 \mathrm{~kg}$ of inoculum, $0.5 \mathrm{~kg}$ of water, $0.3 \mathrm{~kg}$ of grass) to attain an inoculum:substrate VS ratio equal to 2:1), as suggested by standard Biomethane Potential (BMP) tests [29].

Two cycles of tests were conducted in mesophilic conditions $\left(38^{\circ} \mathrm{C}\right)$ for 40 days, the first with spring grass and the second with summer grass. Net biogas production was determined as the difference between the production of digesters n. 4, 5 and 6 and the residual production measured in reactors n. 1,2, and 3. BMP, referred to the mass unit of organic matter (VS) contained in input grass ( $\mathrm{L} \mathrm{CH}_{4} \cdot \mathrm{kgVS}^{-1}$ or $\mathrm{mL} \mathrm{CH}_{4} \cdot \mathrm{gVS}^{-1}$ ), was calculated from the net production of biogas, considering $\mathrm{CH}_{4}$ concentration. The results are reported as average of the three reactors treating spring grass (referred to as Spring) of the three treating summer grass (referred to as Summer).

\subsection{Input and Output Analysis}

Total Solids (TS), Volatile Solids (VS), pH, fibers (cellulose, lignin), Total Kjeldahl Nitrogen (TKN), Lignin, Cellulose, Hemicellulose were determined on input and output of the process [29]. Redox potential was measured by portable $\mathrm{pH} /$ Redox probe (Steiel, Ponte San Nicolò, Italy). Volatile fatty acids (VFA), alkalinity, acidity vs. alkalinity ratio, were determined by a Biogas Titration Manager (Hach Lange, Düsseldorf, Germany).

The digestates from the reactors were subject to the determination of the emissions of $\mathrm{NH}_{3}, \mathrm{CO}_{2}$, $\mathrm{CH}_{4}$ by means of Bruel and Kjiaer 1302 multi-gas analyzer with the static chamber method [30-32]. This method is based on the determination of the increase trend of the concentration of a gas in an enclosed chamber, as consequence of the emission from a sample, until the saturation is reached. A continuous measurement for approximately $20-30 \mathrm{~min}$ is performed, depending on the time in which the gas concentration increase linearly, before reaching saturation. Redox potential, $\mathrm{pH}$, feedstock temperature, and ambient temperature were also measured at the beginning of each measurement run.

The specific flow of the monitored gas $\left(\mathrm{F}_{\text {gas }}\right)$, also defined as emissivity $\left(\mathrm{mg} \cdot \mathrm{m}^{-2} \cdot \mathrm{h}^{-1} \mathrm{~g}^{-1}\right)$, is obtained by the following equation:

$$
\mathrm{F}_{\text {gas }}=\frac{\mathrm{dC}}{\mathrm{dt}} \times \frac{\mathrm{V}}{\mathrm{A}} \times \frac{1}{\mathrm{M}}
$$

where:

$\mathrm{dC}=$ variation of the concentration of the monitored gas in the time interval $\left(\mathrm{mg} \cdot \mathrm{m}^{-3}\right)$

$\mathrm{dt}=$ time interval $(\mathrm{h})$

$\mathrm{V}=$ inner volume of the static chamber $\left(\mathrm{m}^{3}\right)$;

$\mathrm{A}=$ base area of the chamber, and hence, the emitting area $\left(\mathrm{m}^{2}\right)$;

$\mathrm{M}=$ mass of the sample $(\mathrm{g})$

These analyses were performed on both the inoculum and on digestates from AD of fresh spring and summer grass. To perform these analyses, samples of the feedstocks (inoculum and digestates) were collected in aluminium containers (approximately $250-450 \mathrm{mg}$ per container) immediately after the opening of the digesters. This decision was intended to operate on samples at temperatures close to the $38^{\circ} \mathrm{C}$ of the $\mathrm{AD}$ process, minimizing the effect of ambient temperature (lower temperatures determine reduced emissions) and of time, as the emissivity diminishes with time for effect of loss of gaseous compounds. This would be a "worst case scenario" and emissions would be expected to be lower in the field. 


\section{Results and Discussion}

\subsection{Characteristics of the Feedstocks}

Grass was composed mainly by Poaceae, with prevalence of Poa spp. and Festuca spp. in the spring and Poa spp., Festuca spp., Sorghum spp., and Phragmites spp. for the summer samples. Minor percentages of other species, such as, Asteraceae spp., Equisetaceae spp. and Polygonaceae spp. were also detected [33].

The characteristics of spring grass, summer grass, of the inoculum, and of the final digestate obtained at the end of each test are reported in Table 1. Spring grass samples and summer grass samples presented similar TS content, $32.43 \%$ and $33.30 \%$, respectively; VS resulted $79.21 \%$ TS for the spring grass samples and manifested $90.21 \%$ TS for the summer grass samples.

Relevant differences were detected in terms of content of fibers: spring grass presented lignin, cellulose, and hemicellulose concentrations of 3.93\%TS, $21.24 \% \mathrm{TS}$ and $23.07 \% \mathrm{TS}$, respectively, whereas summer grass revealed concentrations of $8.65 \% \mathrm{TS}, 34.72 \% \mathrm{TS}$ and $28.12 \% \mathrm{TS}$. This difference is related to the natural growth of the plants, but has relevance in terms of degradability, taking into account that fibers, lignin especially, have limited degradability in the AD process and in acceptable period of time (HRT) [34].

The inoculum presented typical characteristics of a digestate from a mesophilic, complete mix digester operating wet fermentation. Considering that the biogas plant is fed with a single feedstock (manure from dairy cows) the characteristics of the samples of the spring and summer tests resulted analogous. The TS of the inoculum resulted $7.85 \%$ in the spring test and of $7.28 \%$ in the summer test, typical concentration of solids for a wet AD process $[35,36]$. Furthermore, the VS content did not vary significantly from $80.80 \%$ TS for the spring test and $78.45 \%$ TS for the summer.

The input mix for the spring test presented a TS concentration of $8.90 \%$ while the summer mix presented a TS concentration of $8.55 \%$. In both cases, this is typical of a wet AD process and is adequate to achieve an efficient mixing/stirring of the substrates [36].

Digestates collected at the completion of the tests presented a significant reduction in terms of TS, resulting in $6.28 \%$ and $6.06 \%$ respectively for spring and summer, as effect of the degradation of the organic matter by AD populations.

VS reduction, in fact, resulted of $38.6 \%$ and of $35.0 \%$ for spring and summer, respectively. These findings demonstrate appropriate degradation of the organic matter but exhibit a slightly lower degradation for summer grass, presumably as effect of the higher concentration of fibers, lignin in particular.

Nitrogen concentration of the inoculum resulted quite constant and typical for a biogas plant fed with dairy manure, with TKN of $4.19 \mathrm{~g} \cdot \mathrm{kg}^{-1}$ and $\mathrm{NH}_{4}^{+}$of $2.92 \mathrm{~g} \cdot \mathrm{kg}^{-1}$ for the spring sample and with TKN of $3.94 \mathrm{~g} \cdot \mathrm{kg}^{-1}$ and $\mathrm{NH}_{4}^{+}$of $3.07 \mathrm{~g} \cdot \mathrm{kg}^{-1}$ for the summer sample. Spring grass presented a TKN concentration of $7.65 \mathrm{~g} \cdot \mathrm{kg}^{-1}$, while summer grass of $10.22 \mathrm{~g} \cdot \mathrm{kg}^{-1}$.

Nitrogen concentration in the mix of the spring grass test presented a TKN of $3.90 \mathrm{~g} \cdot \mathrm{kg}^{-1}$ and $\mathrm{NH}_{4}^{+}$of $2.21 \mathrm{~g} \cdot \mathrm{kg}^{-1}$ whereas digestate presented TKN of $3.90 \mathrm{~g} \cdot \mathrm{kg}^{-1}$ and $\mathrm{NH}_{4}^{+}$of $2.29 \mathrm{~g} \cdot \mathrm{kg}^{-1}$. For the summer grass test digestate the mix presented a TKN of $3.84 \mathrm{~g} \cdot \mathrm{kg}^{-1}$ and $\mathrm{NH}_{4}^{+}$of $2.22 \mathrm{~g} \cdot \mathrm{kg}^{-1}$ and for digestate a TKN of $3.83 \mathrm{~g} \cdot \mathrm{kg}^{-1}$ and $\mathrm{NH}_{4}^{+}$of $2.53 \mathrm{~g} \cdot \mathrm{kg}^{-1}$ was reported. These values indicate that the appropriate mixing of the inoculum with grasses did not determine a significant increase of Nitrogen concentration in the mixture subject to $\mathrm{AD}$ process, maintaining $\mathrm{NH}_{4}^{+}$concentration below toxicity values [33]. Furthermore, TKN was not reduced by the AD process while $\mathrm{NH}_{4}^{+}$was slightly increased as effect of the degradation of proteins.

Redox potential represents a valid indication of the reductive or oxidative conditions in a substrate. The inoculum presented a Redox potential of $-400 \mathrm{mV}$ and $-395 \mathrm{mV}$, while digestates of $-391 \mathrm{mV}$ and $-455 \mathrm{mV}$ for spring and summer grass respectively, to indicate appropriate anaerobic conditions [33].

The acidity/alkalinity ratio of the inoculum resulted in 0.24 for the spring and 0.19 for the summer. These values are close to the lower end of the optimal range of $0.20-0.50$ [37] indicating a favourable 
degradation of acids by the methanogenic bacteria, not only underlining a successful process, but also that the organic load was quite low. In this specific case the performance of the full scale digester was optimal and these value could be a reference of the standard operating conditions of this specific plant. The identical parameter applied to the analysis of digestate from the lab scale tests, conducted in discontinuous conditions, clearly indicates a satisfactory degradation of the feedstock with optimal conversion of acids into methane. In fact, digestate from the spring test, presented a ratio of 0.15 , while digestate from the summer test a ratio of 0.19 .

\subsection{Biogas Quality}

Biogas quality, in terms of $\mathrm{CH}_{4}, \mathrm{CO}_{2}$ and $\mathrm{H}_{2} \mathrm{~S}$ concentration, is reported in Figure 3. Each plot represents the average of the three digesters for each test cycle. The reactors treating spring grass produced a biogas with constant composition for the entire 40-days of the test. $\mathrm{CH}_{4}$ content varied from a minimum of $46.0 \%$, recorded at the beginning of the process (day n. 3), to a maximum of $55.2 \%$, recorded three days after (day n. 6), and subsequently remained quite constant and close to the average value of $51.5 \pm 1.4 \%$, with maximum of $55.2 \%$ and minimum of and $\mathrm{CO}_{2}$ concentration of $46.3 \pm 1.4 \%$. Average $\mathrm{CO}_{2}$ concentration resulted in $46.3 \pm 1.4 \%$, with maximum of $53.0 \%$ recorded at day n. 3 when the methanogenic production was not fully developed, and with a minimum of $43.6 \%$.

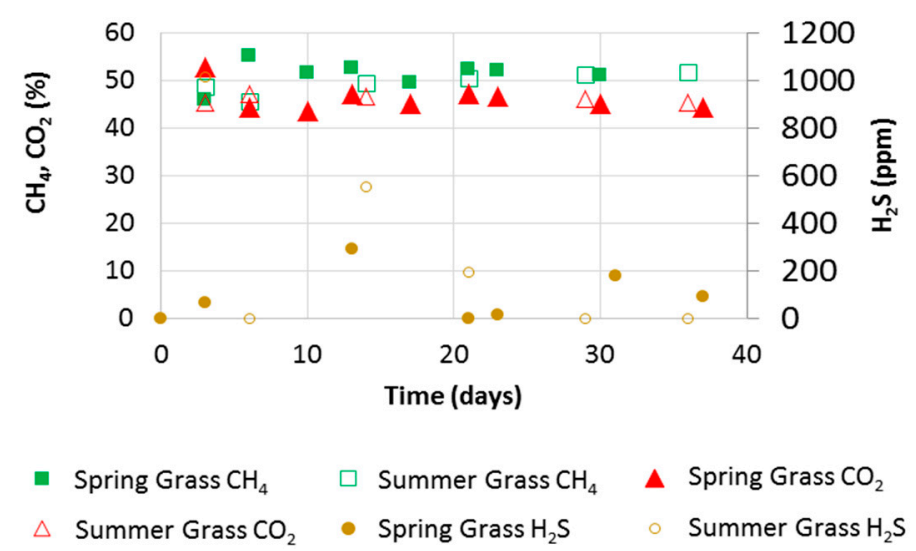

Figure 3. Biogas quality in terms of $\mathrm{CH}_{4}, \mathrm{CO}_{2}$ and $\mathrm{H}_{2} \mathrm{~S}$ concentration.

Spring grass revealed a methane concentration quite typical for co-digestion $[1,16,34,36]$. The concentration of $\mathrm{H}_{2} \mathrm{~S}$ resulted significantly variable with time, ranging from a minimum below the detecting threshold ( $25 \mathrm{ppm}$ ) to a peak of $295 \mathrm{ppm}$ corresponding to day $\mathrm{n}$. 13, after the production peak of day $n$. 6 . The evolution of this parameter is not very clear, but the average concentration is well below the limit of $300 \mathrm{ppm}$ referred as safe threshold for Combined Heat and Power (CHP) units, and also the peak is acceptable without the potential need of $\mathrm{H}_{2} \mathrm{~S}$ removal systems.

Summer grass also showed a relatively constant biogas quality, in reference to $\mathrm{CH}_{4}$ and $\mathrm{CO}_{2}$, with variations from a minimum of $45.6 \%$ (day n. 6) to a maximum of $55.2 \%$ (day n. 36 ). $\mathrm{CH}_{4}$ concentration exceeded $50 \%$ only after day n. 21, exhibiting a slower methanogenic activity compared to spring grass, that reached the maximum around day n. 6. Average $\mathrm{CH}_{4}$ concentration resulted $49.7 \pm 1.2 \%$, lower than spring grass and of typical co-digestion values.

$\mathrm{CO}_{2}$ concentration ranged from a minimum of $45.4 \%$ (day n. 36 corresponding to maximum $\mathrm{CH}_{4}$ concentration) to a maximum of $47.5 \%$ (day n. 21 , minimum $\mathrm{CH}_{4}$ ), with average $46.4 \pm 1.4 \%$.

$\mathrm{H}_{2} \mathrm{~S}$ concentration in biogas from summer grass demonstrated higher variations compared to spring grass, with the highest registered value of $1016.7 \mathrm{ppm}$ at day n. 3, followed by a lower peak of $556.7 \mathrm{ppm}$ at day n. 13. These peaks exceed the threshold of $300 \mathrm{ppm}$ considered as admissible for $\mathrm{CHP}$ use of biogas and suggest treatments for $\mathrm{H}_{2} \mathrm{~S}$ removal. The average value resulted acceptable, $295.1 \mathrm{ppm}$. Nevertheless, $\mathrm{H}_{2} \mathrm{~S}$ concentration recorded in both tests could be effectively reduced even with biological removal by Thiobacillus under micro-aeration conditions: Mulbry et al. [38] 
determined desulfurization efficiencies ranging from 74 to $>99 \%$ treating biogases that, when untreated, presented $\mathrm{H}_{2} \mathrm{~S}$ concentration from 800 to $7500 \mathrm{mg} \cdot \mathrm{m}^{-3}$.

Overall, biogas quality was acceptable in both tests, but resulted higher for spring grass. This could be related to the different composition of the two grasses, mainly in terms of fiber content, which was higher for summer grass.

$\mathrm{Yu}$ and colleagues [39] report higher concentration of methane (average 71\%) in biogas from grass, in a two-phase AD process, more similar to a dry AD process with recirculation of leachate [36] but simulating degradation times of a landfill. This result could be explained by the different chemical composition of grass and different AD processes. Other studies determined that the concentration of $\mathrm{CH}_{4}$ from $\mathrm{AD}$ of grass can vary depending on the $\mathrm{AD}$ system, showing values of $71 \%$ for Upflow Anaerobic Sludge Blanket digesters, 51-54\% for smaller scale BMP units, and 52\% for continuous-flow stirred tank reactor (CSTR) digesters [40].

\subsection{Biogas Production and Yield}

Biogas production of the single reactors, for both spring and summer tests, is reported in Figure 4.
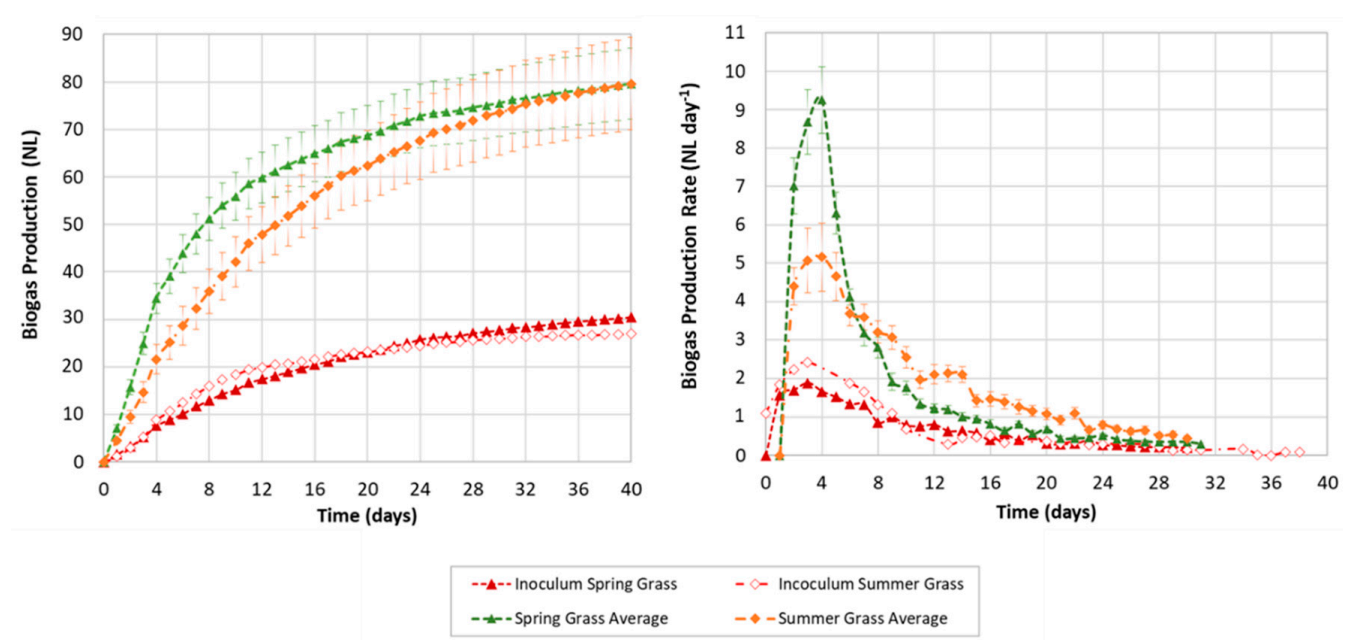

Figure 4. Average cumulated biogas production (left) and daily (right) production rate of the two runs.

Total cumulated biogas production of the two inoculums resulted similar in the two test runs. Residual production of biogas resulted $30.6 \mathrm{NL}$ for the spring test and of $27.0 \mathrm{NL}$ for the summer test. It is notable how digestate from the cow farm (HRT 30 days) still presented some biogas potential after 40 days of anaerobic digestion. A reactor with increased volume (higher HRT) would probably allow the farm to obtain more energy from manure. This also can indicate that the standard BMP procedure of allowing the inoculum degasify for a week may be not sufficient to completely eliminate the residual production.

The curves of biogas production depict the evolution of the comprehensive production, inclusive also of the residual production of the inoculum.

For spring grass, in particular, the three reactors presented a continuous production that showed higher intensity in the first days, as highlighted by a peak in the daily production corresponding to day n. 3. The average peak resulted in $9.3 \mathrm{NL} \cdot$ day $^{-1} \pm 0.9$. The average final biogas production resulted in with average production of $79.9 \mathrm{NL} \pm 7.5$.

The biogas production curves for summer grass demonstrated a similar but less steep trend. Also in this case a peak in the daily production was detected for all the digesters corresponding to day n. 3, with average peak of $5.2 \mathrm{NL} \cdot$ day $^{-1} \pm 0.9$. Obtained values resulted lower than the peaks recorded for spring grass ( $44 \%$ lower with respect to the average values). This result did not affect the final production, which resulted notably analogous to that from spring grass, with average of $80.1 \mathrm{NL} \pm 9.8$. Figure 4 shows that the daily production curves of summer grass, despite a lower peak 
compared to spring grass, presented a lower decrease after the maximum resulting in a more constant production, reaching a similar final volume of biogas.

Biogas production from spring grass reached $50 \%$ in correspondence to day $\mathrm{n} .5$ and $80 \%$ at day n. 15 , while biogas production from summer grass reached $50 \%$ in correspondence to day n. 9 and $80 \%$ at day n. 21.

This difference could be explained by taking into account the higher content of fibers of summer grass, with consequent slower production rate. On the other hand, spring grass presented an initial higher production rate that diminished when the easily degradable organic matter was transformed into biogas. Other studies performed in a leach bed upflow anaerobic sludge blanket (UASB) process, with higher HRT, showed that $58 \%$ of the acid soluble lignin was solubilized within the 49 days of process, whereas lignin was most recalcitrant [27].

The net production of biogas from both spring and summer grass, was calculated by subtracting the recorded values of the residual production of the inoculums and was referred to mass units of raw product, of TS and of VS (Figure 5). The trends remained quite comparable to those depicted in Figure 4, with highest peaks reported for spring grass but steadier production for summer grass. After day n.8, the daily production of summer grass surpassed the daily production of spring grass.
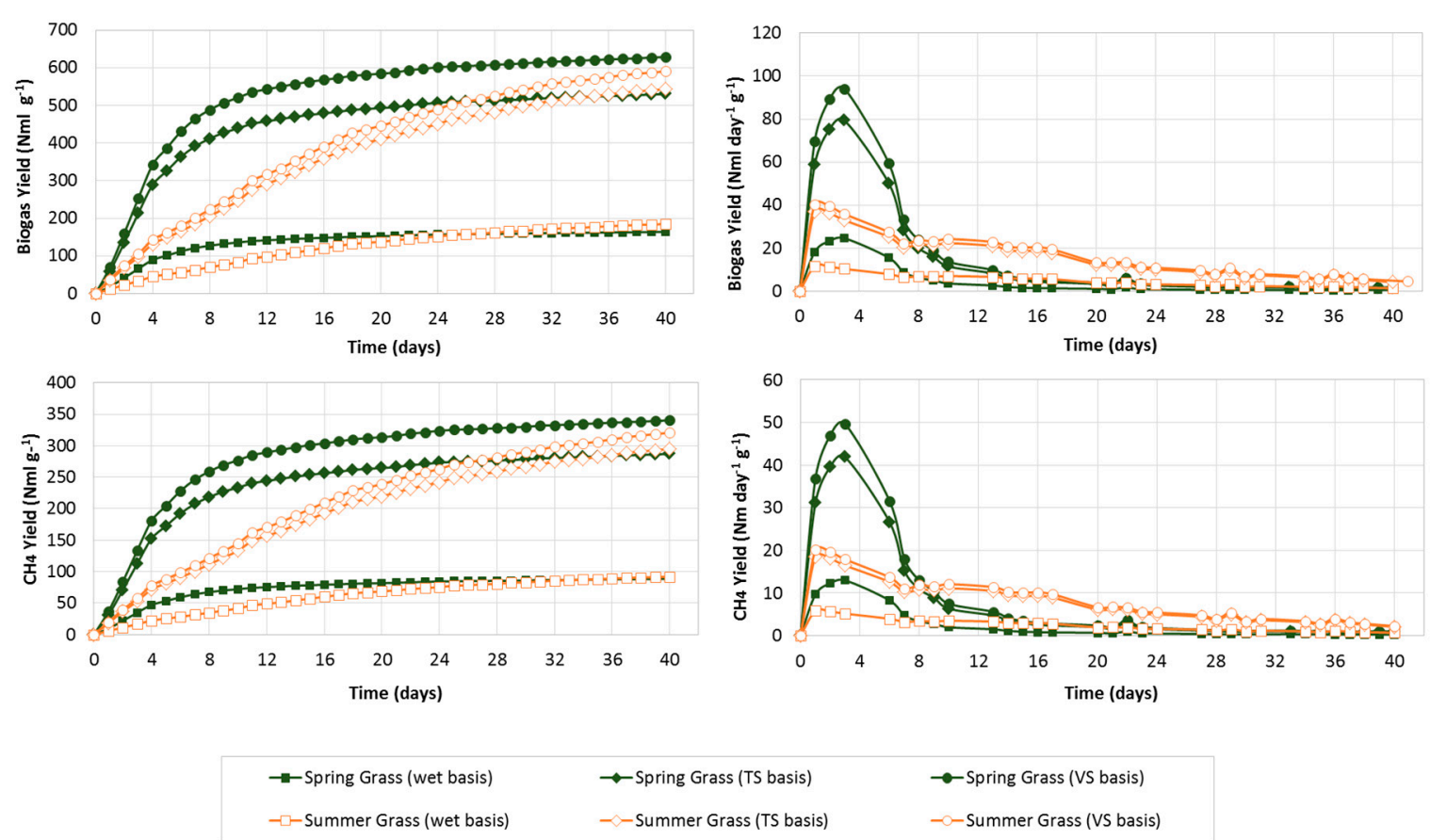

Figure 5. Cumulated (top left), daily (top right) biogas yield and cumulated (below left), daily (below right) $\mathrm{CH}_{4}$ yield referred to mass unit of wet product, of TS and VS.

Biogas yield of spring grass resulted in $164.6 \mathrm{NL} \cdot \mathrm{kg}^{-1}$ (wet mass), $507.5 \mathrm{NL} \cdot \mathrm{kg}^{-1} \mathrm{TS}$ and $640.7 \mathrm{NL} \cdot \mathrm{kg}^{-1} \mathrm{VS}$; for summer grass a biogas yield of $186.1 \mathrm{NL} \cdot \mathrm{kg}^{-1}$ (wet mass), $558.8 \mathrm{NL} \cdot \mathrm{kg}^{-1} \mathrm{TS}$ and $619.1 \mathrm{NL} \cdot \mathrm{kg}^{-1} \mathrm{VS}$ (Figure 6). Results can be considered comparable, despite the higher production that was achieved, in reference to wet mass and TS, for summer grass and for spring grass in reference to VS.

Methane yield resulted in $87.4 \mathrm{NL} \cdot \mathrm{kg}^{-1}$ (wet mass), $269.5 \mathrm{NL} \cdot \mathrm{kg}^{-1} \mathrm{TS}$ with BMP of $340.2 \mathrm{NL} \cdot \mathrm{kg}^{-1} \mathrm{VS}$ for spring grass and $92.5 \mathrm{NL} \cdot \mathrm{kg}^{-1}$ (wet mass), $277.7 \mathrm{NL} \cdot \mathrm{kg}^{-1} \mathrm{TS}$ with BMP of $307.7 \mathrm{NL} \cdot \mathrm{kg}^{1} \mathrm{VS}$ for summer grass. 


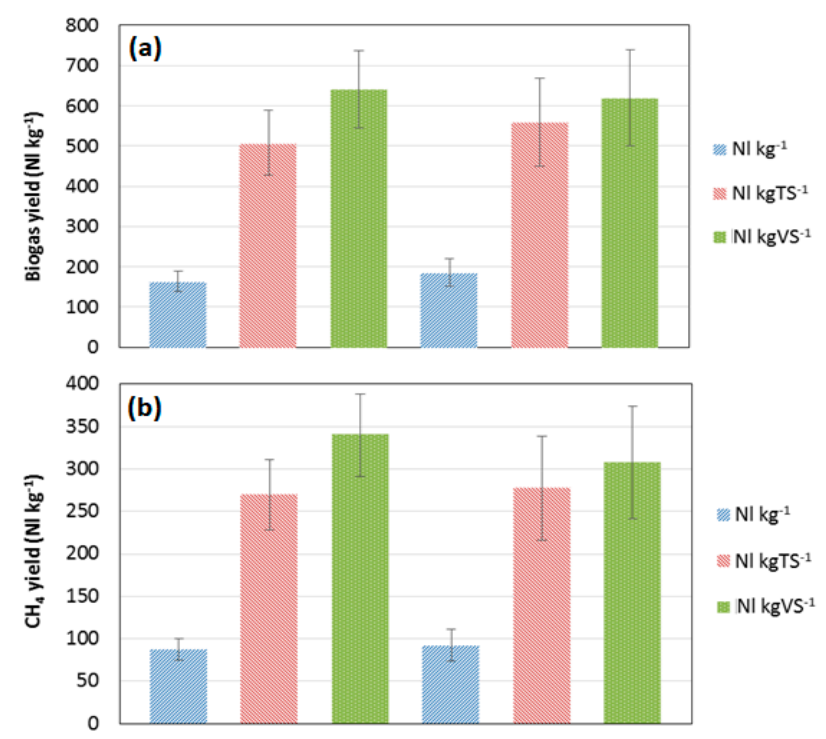

Figure 6. Biogas (a) and methane yield (b) of spring and summer grass, referred to wet mass, total solids and volatile solids.

The biogas yield of grass was higher than expected, similar to the yield from energy crops, especially in terms of $\mathrm{NL} \cdot \mathrm{kg}^{-1} \mathrm{VS}[33,34]$. Other authors reported BMP values of $337 \mathrm{NL} \cdot \mathrm{kg}^{-1} \mathrm{VS}$ for a mixture of switchgrass and swine manure without assessing the specific yield from grass [26].

Methane potential varying from 0.141 to $0.204 \mathrm{~m}^{3} \cdot \mathrm{CH}_{4} \mathrm{~kg}^{-1}$ added volatile solids was obtained by Lehtomäki and collegues [27], while other authors report a BMP from ensiled grass varying from 350 to $493 \mathrm{~L} \mathrm{CH}_{4} \cdot \mathrm{kg}^{-1} \mathrm{VS}$ for three different AD processes, with $451 \mathrm{~L} \mathrm{CH}_{4} \cdot \mathrm{kg}^{-1} \mathrm{VS}$ for a CSTR system over a 50-day retention period [40]. Grass characteristics, eventual conservation, and AD process are essential parameters influencing BMP of grass.

Grass production per surface of land resulted in $3.01 \mathrm{t} \cdot \mathrm{ha}^{-1}$, wet mass, and $0.98 \mathrm{t} \cdot \mathrm{ha}^{-1}$, dry mass, in the spring $12.78 \mathrm{t} \cdot \mathrm{ha}^{-1}$ wet mass, and $3.89 \mathrm{t} \cdot \mathrm{ha}^{-1}$, dry mass, in the summer. These results are related to the fact that the harvest was performed in two different areas rather than in two subsequent cuts in the same area.

The production of biogas and methane per surface of grassland was calculated intersecting biogas and methane yields and grass production (wet mass). The results revealed a biogas yield of 496 $\mathrm{Nm}^{3} \cdot \mathrm{ha}^{-1}$ for spring grass and $2377 \mathrm{Nm}^{3} \cdot \mathrm{ha}^{-1}$ for summer grass, while methane yield resulted in 263 $\mathrm{Nm}^{3} \cdot \mathrm{ha}^{-1}$ and $1181 \mathrm{Nm}^{3} \cdot \mathrm{ha}^{-1}$, respectively (Figure 7).

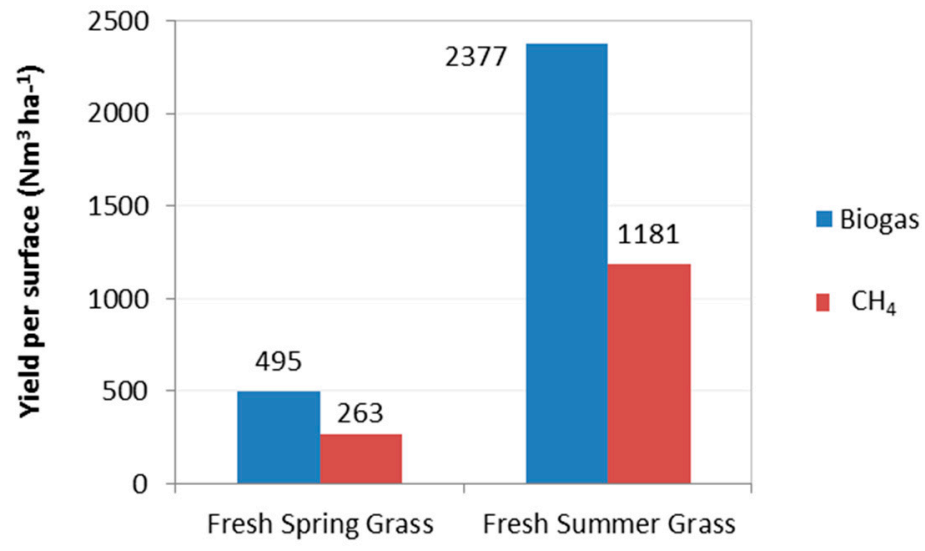

Figure 7. Biogas and methane yield per surface of grassland (expressed as hectares). 
Other authors report a methane yield of 2700 and $3500 \mathrm{Nm}^{3} \cdot \mathrm{ha}^{-1}$ for Alpine grassland [2]. Clearly this result is strictly related to the investigated areas and influenced by several factors including grass species, biomass production and harvesting period as result of different climate conditions and soil characteristics. In terms of energy, considering a specific heating value of $37.7 \mathrm{MJ} \cdot \mathrm{m}^{-3}$, the results of the present study demonstrate a potential energy yield of $9915 \mathrm{MJ} \cdot \mathrm{ha}^{-1}$ for spring grass and $44,523 \mathrm{MJ} \cdot \mathrm{ha}^{-1}$ for summer grass.

\subsection{Gaseous Emissions}

Gaseous emissions from the inoculum and from digestates from anaerobic digestion of fresh spring and summer grass, reported as specific emissivity per unit of emitting surface and mass unit of sample $\left(\mathrm{mg} \cdot \mathrm{h}^{-1} \cdot \mathrm{m}^{-2} \mathrm{~g}^{-1}\right.$ for $\mathrm{NH}_{3}$ and $\mathrm{CH}_{4}$ and $\mathrm{g} \cdot \mathrm{h}^{-1} \cdot \mathrm{m}^{-2} \mathrm{~g}^{-1}$ for $\left.\mathrm{CO}_{2}\right)$, are reported in Figure 8.

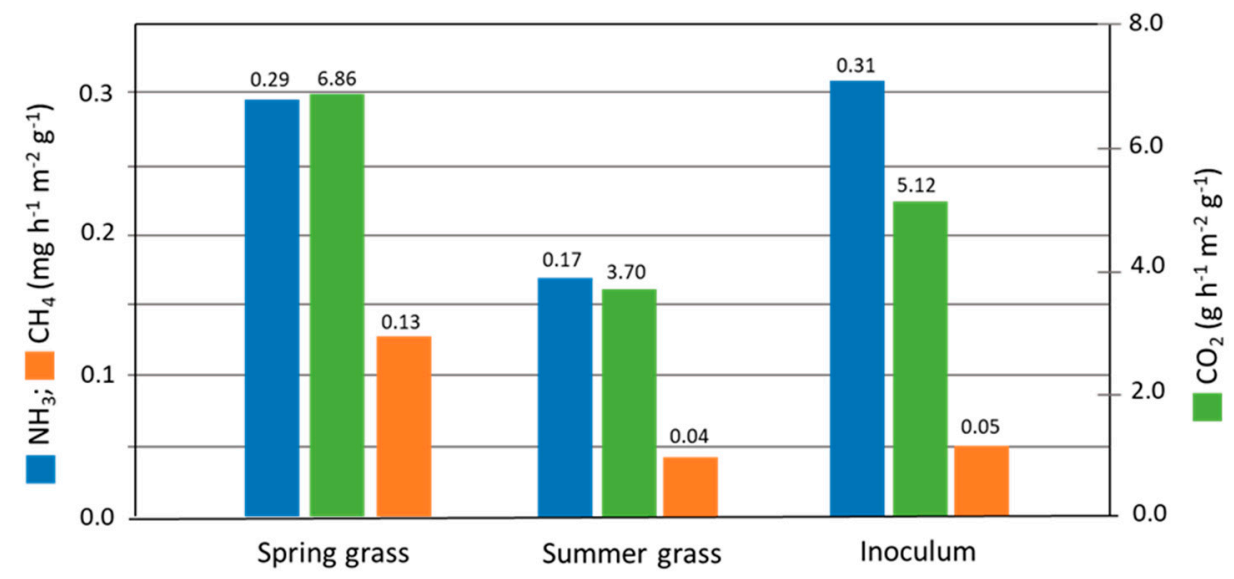

Figure 8. Specific gaseous emissions from inoculum and digestates from AD of fresh spring and summer grass.

Ammonia emissions revealed $0.310 \mathrm{mg} \cdot \mathrm{h}^{-1} \cdot \mathrm{m}^{-2} \mathrm{~g}^{-1}$ for the inoculum, 0.293 and $0.170 \mathrm{mg} \cdot \mathrm{h}^{-1} \cdot \mathrm{m}^{-2} \mathrm{~g}^{-1}$ for anaerobically digested fresh spring and summer grass, respectively. Whereas spring grass seems to release a similar quantity of ammonia compared to digestate, summer grass appears to emit less. This result is inconsistent with the concentration of $\mathrm{N}$ of grass, higher for summer grass.

Methane emissions resulted in $0.049 \mathrm{mg} \cdot \mathrm{h}^{-1} \cdot \mathrm{m}^{-2} \mathrm{~g}^{-1}$ for the inoculum, of 0.129 and $0.043 \mathrm{mg} \cdot \mathrm{h}^{-1} \cdot \mathrm{m}^{-2} \mathrm{~g}^{-1}$ for fresh spring and summer grass, respectively. Furthermore, carbon dioxide, revealed specific emission of $5.124 \mathrm{~g} \cdot \mathrm{h}^{-1} \cdot \mathrm{m}^{-2} \mathrm{~g}^{-1}$ for the inoculum, 6.858 and $3.696 \mathrm{~g} \cdot \mathrm{h}^{-1} \cdot \mathrm{m}^{-2} \mathrm{~g}^{-1}$ for anaerobically digested fresh spring and summer grass, respectively. These results can be considered as a reference more than providing indication of different emission rates between the feedstocks. In fact, a certain variability is related to the variations in the atmospheric conditions, temperature of air, in particular, between the different measurement campaigns. Alternatively, it would be meaningful to evaluate the emissions of greenhouse and acidifying gases from anaerobic digestion in comparison with traditional management practices, like composting of grass.

Nevertheless, the results are not intended as simulation of real conditions in which digestate is conveyed to a storage tank, in many cases equipped with airtight cover, where is stored for months before being applied on cropland.

\section{Conclusions}

The biogas yield obtained from grass resulted higher than expected, quite similar to the yield obtained from energy crops, especially in terms of volume per mass unit of volatile solids ( $\mathrm{NL} \cdot \mathrm{kg}^{-1} \mathrm{VS}$ ).

This promising result can be related to the fact that grass was loaded in the digesters just few hours after being collected, with the maximum availability of organic matter. However, iunder actual 
operative conditions, storage of feedstocks is required, with possible loss of VS and consequently lower biogas potential.

The specific yield of spring and summer grass, both in terms of biogas and methane, revealed similarities between the two types of feedstocks. Biogas quality resulted slightly lower for summer grass, perhaps in relation to the higher content of fibers (lignin in particular). Alternatively, the yield of grass per surface was significantly different between spring and summer, with the highest production in the summer. This difference also affects the biogas and methane yield per hectare resulting more than 4 times higher for the summer grass. It is clear that the results in terms of grass yield, characteristics, and BMP are influenced by the specific conditions (e.g., climate, soil properties) of the investigated area and may result different in other geographic areas.

The present research indicates that grass can be successfully utilized as feedstock in the anaerobic digestion process, resulting in the production of biogas or biomethane, with acceptable HRT. This result opens the prospective of recovering this feedstock from various areas, including parks, riverbanks, or public areas etc. In theory, lower HRT could be taken in consideration for spring grass, but in practice this would be impractical and could result in an incorrect sizing of the reactors in case of employing of other feedstocks, such as summer grass itself.

For a practical exploitation of this resource, appropriate conservation of the feedstock is necessary, by storing grass in order to enable the daily load of digesters while reducing the loss of organic matter (e.g., biogas potential). To simulate operative conditions in relation to the most common conservation practices, spring and summer grass were air dried and ensiled, and BMP was assessed. The results of the last anaerobic digestion tests will be object of a further paper.

Author Contributions: Conceptualization, A.C., A.P., D.B., F.d.B., and L.S.; Methodology, A.C., A.P., D.B., F.d.B., and L.S.; Software, A.C., A.P., and D.B.; Validation, A.C., A.P., F.d.B., and D.B.; Formal Analysis, A.C., A.P., F.d.B., and D.B.; Investigation, A.C., A.P., F.d.B., and D.B.; Resources, L.S., and F.d.B.; Data Curation, A.C., A.P., F.d.B., and D.B.; Writing-Original Draft Preparation, A.C., A.P., and F.d.B.; Writing-Review \& Editing, A.C., A.P., and F.d.B.; Visualization, A.C., A.P., and F.d.B.; Supervision, L.S., and F.d.B.; Project Administration, L.S., and F.d.B.; Funding Acquisition, L.S., and F.d.B.

Acknowledgments: The authors would like to thank Penny Lazo for the professional and kind support for the proof reading and English language editing of the paper and Amedeo Bizzotto for the precious assistance in the tests.

Conflicts of Interest: The authors declare no conflict of interest.

\section{References}

1. Diaz, L.F.; Chiumenti, A.; Savage, G.M.; Eggerth, L.L. Managing the Organic fraction of Municipal Solid Waste. BioCycle 2006, 47, 50-54.

2. Amon, T.; Amon, B.; Kryvoruchko, V.; Machmüller, A.; Hopfner-Sixt, K.; Bodiroza, V.; Hrbek, R.; Friedel, J.; Pötsch, E.; Wagentristl, H.; et al. Methane production through anaerobic digestion of various energy crops grown in sustainable crop rotations. Bioresour. Technol. 2007, 98, 3204-3212. [CrossRef] [PubMed]

3. Appels, L.; Lauwers, L.; Degrève, J.; Helsen, L.; Lievens, B.; Willems, K.; Van Impe, J.; Dewil, R. Anaerobic digestion in global bio-energy production: Potential and research challenges. Renew. Sustain. Energy Rev. 2011, 15, 4295-4301. [CrossRef]

4. Coppolecchia, D.; Gardoni, D.; Baldini, C.; Borgonovo, F.; Guarino, M. The influence on biogas production of three slurry-handling systems in dairy farms. J. Agric. Eng. 2015, 46, 30-35. [CrossRef]

5. Pezzuolo, A.; Dumont, B.; Sartori, L.; Marinello, F.; Migliorati, M.D.A.; Basso, B. Evaluating the impact of soil conservation measures on soil organic carbon at the farm scale. Comput. Electron. Agric. 2017, 135, $175-182$. [CrossRef]

6. Oviedo-Ocaña, E.R.; Dominguez, I.; Torres-Lozada, P.; Marmolejo-Rebellón, L.F.; Komilis, D.; Sanchez, A. A qualitative model to evaluate biowaste composting management systems using causal diagrams: A case study in Colombia. J. Clean. Prod. 2016, 133, 201-211. [CrossRef]

7. Gerin, P.A.; Vliegen, F.; Jossart, J.M. Energy and $\mathrm{CO}_{2}$ balance of maize and grass as energy crops for anaerobic digestion. Bioresour. Technol. 2008, 99, 2620-2627. [CrossRef] [PubMed] 
8. Pöschl, M.; Ward, S.; Owende, P. Evaluation of energy efficiency of various biogas production and utilization pathways. Appl. Energy 2010, 87, 3305-3321. [CrossRef]

9. Da Borso, F.; Chiumenti, A.; Sigura, M.; Pezzuolo, A. Influence of automatic feeding systems on design and management of dairy farms. J. Agric. Eng. 2017, 48, 48-52. [CrossRef]

10. Chiumenti, R.; Chiumenti, A.; da Borso, F.; Limina, S.; Landa, A. Anaerobic Digestion of Swine Manure in Conventional and Hybrid Pilot Scale Plants: Performance and Gaseous Emissions Reduction. In Proceedings of the International Syposium (ASABE 2009), Reno, NV, USA, 21-24 June 2009.

11. Dinuccio, E.; Balsari, P.; Gioelli, F.; Menardo, S. Evaluation of the biogas productivity potential of some Italian agro-industrial biomasses. Bioresour. Technol. 2010, 101, 3780-3783. [CrossRef] [PubMed]

12. Valenti, F.; Porto, S.M.; Cascone, G.; Arcidiacono, C. Potential biogas production from agricultural by-products in Sicily. A case study of citrus pulp and olive pomace. J. Agric. Eng. 2017, 48, $196-202$. [CrossRef]

13. Eggerth, L.L.; Diaz, L.F.; Chang, M.T.F.; Iseppi, L. Marketing of composts. Waste Manag. 2007, 8, 325-355.

14. Boscaro, D.; Pezzuolo, A.; Grigolato, S.; Cavalli, R.; Marinello, F.; Sartori, L. Preliminary analysis on mowing and harvesting grass along riverbanks for the supply of anaerobic digestion plants in north-eastern Italy. J. Agric. Eng. 2015, 46, 100-104. [CrossRef]

15. Blokhina, Y.N.; Prochnow, A.; Plöchl, M.; Luckhaus, C.; Heiermann, M. Concepts and profitability of biogas production from landscape management grass. Bioresour. Technol. 2011, 102, 2086-2092. [CrossRef] [PubMed]

16. Hansen, C.; Zhong, J.; Hansen, J. Anaerobic digestion of dairy processing waste, algae, and grass in pilot and full scale. Trans. ASABE 2014, 57, 609-614.

17. Boscaro, D.; Pezzuolo, A.; Sartori, L.; Marinello, F.; Mattioli, A.; Bolzonella, D.; Grigolato, S. Evaluation of the energy and greenhouse gases impacts of grass harvested on riverbanks for feeding anaerobic digestion plants. J. Clean. Prod. 2018, 172, 4099-4109. [CrossRef]

18. Mattioli, A.; Boscaro, D.; Dalla Venezia, F.; Santacroce, F.C.; Pezzuolo, A.; Sartori, L.; Bolzonella, D. Biogas from residual grass: A territorial approach for sustainable bioenergy production. Waste Biomass. Valoriz. 2017, 8, 2747-2756. [CrossRef]

19. Colantoni, A.; Delfanti, L.; Recanatesi, F.; Tolli, M.; Lord, R. Land use planning for utilizing biomass residues in Tuscia Romana (central Italy): Preliminary results of a multi criteria analysis to create an agro-energy district. Land Use Policy. 2016, 50, 125-133. [CrossRef]

20. Bonzini, S.; Verro, R.; Otto, S.; Lazzaro, L.; Finizio, A.; Zanin, G.; Vighi, M. Experimental validation of a geographical information systems-based procedure for predicting pesticide exposure in surface water. Environ. Sci. Technol. 2006, 40, 7561-7569. [CrossRef] [PubMed]

21. Pappalardo, S.; Prosdocimi, M.; Tarolli, P.; Borin, M. Assessment of Energy Potential from Wetland Plants along the Minor Channel Network on an Agricultural Floodplain. Environ. Sci. Pollut. Res. 2014, 22, 2479-2490. [CrossRef] [PubMed]

22. Hensgen, F.; Richter, F.; Wachendorf, M. Integrated generation of solid fuel and biogas from green cut material from landscape conservation and private households. Bioresour. Technol. 2011, 102, 10441-10450. [CrossRef] [PubMed]

23. Tsapekos, P.; Kougias, P.G.; Egelund, H.; Larsen, U.; Pedersen, J.; Trénel, P.; Angelidaki, I. Mechanical pretreatment at harvesting increases the bioenergy output from marginal land grasses. Renew. Energy. 2017, 111, 914-921. [CrossRef]

24. Bishop, G.C.; Burns, R.T.; Shepherd, T.A.; Moody, L.B.; Gooch, C.A.; Spajic, R.; Pronto, J. Evaluation of laboratory biochemical methane potentials as a predictor of anaerobic dairy manure digester biogas and methane production. In Proceedings of the American Society of Agricultural and Biological Engineers Annual International Meeting, Reno, NV, USA, 21-24 June 2009; pp. 5254-5265.

25. Safferman, S.I.; Kirk, D.M.; Faivor, L.L.; Haan, W.W. Anaerobic digestion processes. In Bioremediation and Sustainability: Research and Applications; Wiley: Hoboken, NJ, USA, 2012; pp. 103-136.

26. Ahn, H.K.; Smith, M.C.; Konrad, S.L.; White, J.W. Evaluation of biogas production potential by dry anaerobic digestion of switchgrass-animal manure mixtures. Appl. Biochem. Biotechnol. 2010, 160, 965-975. [CrossRef] [PubMed]

27. Lehtomäki, A.; Huttunen, S.; Lehtinen, T.M.; Rintala, J.A. Anaerobic digestion of grass silage in batch leach bed processes for methane production. Bioresour. Technol. 2008, 99, 3267-3278. [CrossRef] [PubMed] 
28. Xie, S.; Wu, G.; Lawlor, P.G.; Frost, J.P.; Zhan, X. Methane production from anaerobic co-digestion of the separated solid fraction of pig manure with dried grass silage. Bioresour. Technol. 2012, 104, $289-297$. [CrossRef] [PubMed]

29. American Public Health Association (APHA). Standard Methods for the Examination of Water and Wastewater, 21th ed.; APHA: Washington, DC, USA, 2005; pp. 5-41.

30. Chiumenti, A. Complete nitrification-denitrification of swine manure in a full-scale, non-conventional composting system. Waste Manag. 2015, 46, 577-587. [CrossRef] [PubMed]

31. Chiumenti, A.; da Borso, F.; Pezzuolo, A.; Sartori, L.; Chiumenti, R. Ammonia and greenhouse gas emissions from slatted dairy barn floors cleaned by robotic scrapers. Res. Agric. Eng. 2018, 64, $26-33$.

32. Frison, N.; Chiumenti, A.; Katsou, E.; Malamis, S.; Bolzonella, D.; Fatone, F. Mitigating off-gas emissions in the biological nitrogen removal via nitrite process treating anaerobic effluents. J. Clean. Prod. 2015, 93, 126-133. [CrossRef]

33. Chiumenti, A.; Boscaro, D.; da Borso, F.; Sartori, L.; Pezzuolo, A. Anaerobic digestion of grass: Effect of the harvesting period on biogas yield. In Proceedings of the ASABE Annual International Meeting 2017, Spokane, WA, USA, 16-19 July 2017.

34. Baldini, M.; da Borso, F.; Ferfuia, C.; Danuso, F. Ensilage suitability and bio-methane yield of Arundo donax and Miscanthus giganteus. J. Ind. Crops Prod. 2017, 95, 264-275. [CrossRef]

35. Jantrania, A.R.; White, R.K. High-solids anaerobic fermentation of poultry manure. In Proceedings of the Fifth International Symposium on Agricultural Waste, St. Joseph, MI, USA, 16-17 December 1985; pp. 73-80.

36. Chiumenti, A.; da Borso, F.; Limina, S. Dry anaerobic digestion of cow manure and agricultural products in a full-scale plant: Efficiency and comparison with wet fermentation. Waste Manag. 2018, 71, 704-710. [CrossRef] [PubMed]

37. Lossie, U.; Pütz, P. Targeted Control of Biogas Plants with the Help of FOS/TAC; Practice Report Hach-Lange; Hach: Loveland, CO, USA, 2015.

38. Mulbry, W.; Selmer, K.; Lansing, S. Effect of liquid surface area on hydrogen sulfide oxidation during micro-aeration in dairy manure digesters. PLOS ONE 2017, 12, 0185738. [CrossRef] [PubMed]

39. Yu, H.W.; Samani, Z.; Hanson, A.; Smith, G. Energy recovery from grass using two-phase anaerobic digestion. Waste Manag. 2002, 22, 1-5. [CrossRef]

40. Nizami, A.S.; Orozco, A.; Groom, E.; Dieterich, B.; Murphy, J.D. How much gas can we get from grass? Appl. Energy 2012, 92, 783-790. [CrossRef] 